\title{
8- Türkçenin yabancı dil olarak öğretiminde kavram haritaları kullanımının başarıya etkisi
}

\section{Zeki GÜREL'}

\section{Hilal Gülben GEREK²}

APA: Gürel, Z.; Gerek, H. G. (2021). Türkçenin yabancı dil olarak öğretiminde kavram haritaları kullanımının başarıya etkisi. RumeliDE Dil ve Edebiyat Araştırmaları Dergisi, (25), 110-123. DOI: $10.29000 /$ rumelide.1032412.

$\ddot{O} \mathbf{z}$

Türkçeyi yabancı dil olarak öğrenenlerin okuduğunu anlama başarısı üzerinde kavram haritalarının etkisinin araştırıldığı bu çalışmada ön test-son test kontrol gruplu desen kullanılmıştır. Araştırma, 2017-2018 eğitim öğretim yılında Adana Alparslan Türkeş Bilim ve Teknoloji Üniversitesi Türkçe Öğretimi Uygulama ve Araştırma Merkezinde Türkçe öğrenen B1 düzeyindeki 31 yabancı öğrenciyle 6 hafta süreyle gerçekleştirilmiştir. Deney grubunda uygulama boyunca ders kitabındaki okuma metinleri kavram haritalarıyla işlenmiştir. Deneysel işlemin başında ve sonunda deney ve kontrol grubu öğrencilerine araştırmacı tarafindan geliştirilen okuduğunu anlama başarı testleri uygulanmıştır. Ayrıca bu çalışmada deney grubunun okuduğunu anlama başarılarının cinsiyete, yabancı dil bilme durumuna, Türkiye'de bulunma süresine, kitap, gazete, dergi vb. okuma durumuna göre farklılık gösterip göstermediği incelenmiştir. Yapılan analizler neticesinde kavram haritasıyla öğretimin yapıldığı deney grubundaki kız öğrencilerin erkek öğrencilere göre; kitap, gazete, dergi vb. okuyan öğrencilerin okumayanlara göre okuduğunu anlama becerisinde daha başarılı oldukları bulunmuştur. Bununla birlikte okuduğunu anlama becerisinde deney grubunun kontrol grubuna göre daha başarılı olduğu tespit edilmiştir. Kavram haritasıyla yapılan öğretimin mevcut öğretim programına göre öğrencilerin okuduğunu anlama başarısı üzerinde daha etkili olduğu sonucuna ulaşılmıştır.

Anahtar kelimeler: Kavram haritası, okuduğunu anlama başarısı, Türkçenin yabancı dil olarak öğretimi

\section{The effect of use of concept maps on success in teaching Turkish as a foreign language}

\begin{abstract}
In this study, in which the effect of concept maps on the reading comprehension success of those who learn Turkish as a foreign language, the pretest-posttest control group design was used. The study was carried out with 31 foreign students learning Turkish at B1 level at Adana Alparslan Türkeş Science and Technology University, Turkish Teaching Practice and Research Center in the 2017-2018 academic year for 6 weeks. Within the scope of the study, the reading texts in the textbook of the experimental group were taught with concept maps. At the beginning and end of the experimental process, reading comprehension achievement tests developed by the researcher were applied to the
\end{abstract}

Doç. Dr., Gazi Üniversitesi, Gazi Eğitim Fakültesi, Türkçe ve Sosyal Bilimler Eğitimi Bölümü (Ankara, Türkiye), zekigurel@yahoo.com, ORCID ID: 00oo-ooo1-5129-7033 [Araştırma makalesi, Makale kayıt tarihi: 19.10.2021-kabul tarihi: 20.12.2021; DOI: 10.29000/rumelide.1032412]

Öğr. Gör., Adana Alparslan Türkeş Bilim ve Teknoloji Üniversitesi, Türkçe Öğretimi Uygulama ve Araştırma Merkezi (Adana, Türkiye), gulben.gerek@atu.edu.tr, ORCID ID: 0000-0001-7955-8833

Adres | Addres

RumeliDE Dil ve Edebiyat Araştırmaları Dergisi Osmanağa Mahallesi, Mürver Çiçeği Sokak, No:14/8 Kadıköy - ISTANBUL / TÜRKIYE 34714 e-posta: editor@rumelide.com

RumeliDE Journal of Language and Literature Studies Osmanağa Mahallesi, Mürver Çiçeği Sokak, No:14/8

Kadıköy - ISTANBUL / TURKEY 34714 tel: +90 $5057958124,+902167730616$

e-mail: editor@rumelide.com

phone: +90 $5057958124,+902167730616$ 
students in the experimental and control groups. In addition, in this study, it was also evaluated whether the reading comprehension achievements of the experimental group showed difference according to gender, foreign language proficiency, length of live in Turkey, and reading status of books, newspapers, magazines. As a result of the analysis, it has been found that the female students in the experimental group, in which the concept map was taught, compared to the male students; students who read books, newspapers, magazines, etc. are more successful in reading comprehension than those who do not.However, it was determined that the experimental group was more successful than the control group in reading comprehension skills. It has been concluded that teaching with concept maps is more effective on students' reading comprehension success than traditional teaching.

Keywords: Concept map, reading comprehension success, teaching Turkish as a foreign language

\section{Giriş}

Teknolojinin gelişmesi ve küreselleşmenin artmasıyla dünyanın farklı yerlerinde yaşayan insanlar birbirleriyle kolaylıkla iletişim kurabilmektedir. Değişen dünya koşulları doğrultusunda insanların ilgi, talep, ihtiyaç ve beklentileri de değişmektedir. Bu kapsamda birçok insan farklı amaçlarla ana dilinin dışında başka dilleri de öğrenmeye ihtiyaç duymaktadır. Bununla birlikte devletler de dil öğrenmeye olan talebi karşılamak ve değişen dünya koşullarına ayak uydurabilmek için birtakım dil politikalarına yer vermeye başlamıştır. Bu bağlamda yaşadığımız yüzyılda dil öğrenmek kadar dil öğretimi de büyük bir önem arz etmektedir. Bu konuda Yalçın(2012) günümüzde bazı dillerin öğretiminin ticari bir sektör haline gelmesinde iletişimde ve bilginin taşınmasında büyük bir rolü olan dilin önemini vurgulamaktadır. Dünyanın en çok konuşulan dilleri arasında yer alan Türkçenin bu alandaki hızlı gelişimi yakalayabilmesi için dil öğretiminde yapılan bilimsel araştırma sonuçlarının yakından izlenmesinin gerekliliğini ifade etmektedir (s. 9). Bu bağlamda dil öğretimi alanında çağın yakalanabilmesi, bu alanda yapılan bilimsel araştırmaların ve dünyadaki gelişmelerin yakın takibiyle mümkün olabilir.

Son yıllarda Türkiye’ye eğitim almak için gelen yabancı öğrencilerin sayısında artış görülmektedir. Bu durum öğretim programı, programa yönelik ders kitapları, öğreticilerin eğitimi, öğretimde kullanılacak strateji, yöntem ve teknikler gibi dil öğretiminde gerekli olan pek çok konuyu gündeme getirmiştir. Türkçenin yabancı dil olarak öğretiminde önem verilmesi gereken konulardan biri de dil öğretiminde kullanılan yöntem ve tekniklerdir. Demircan (1990), dilin nasıl öğretileceği konusunun yüzyıllardır dil eğitimcilerinin odağında yer aldığını, bu yüzden yabancı dil öğretim yaklaşımları ve yöntemlerinin iyi bilinmesinin ve takip edilmesinin önemini vurgulamaktadır (s.45). Yani, iyi bir dil öğretimi gerçekleştirebilmek için öncelikle etkili ve doğru yöntemin seçilmesi gerekmektedir. Bu kapsamda yirminci yüzyıldan itibaren birçok yeni öğretim stratejisi, yöntem ve teknikler geliştirilmiştir. Bu tekniklerinden biri de kavram haritalarıdır. "İnsanların bilgiyi nasıl öğrendiklerini ve nasıl anlamlandırdıklarını gösteren bir öğrenme- öğretme stratejisi olan kavram haritaları, 1974 yllında Joseph Novak'ın Cornell Üniversitesi öğrencileriyle beraber yürüttükleri bir araştırma projesi sonucunda geliştirilmiştir" (Kaya, 2003, s.266). Kavram haritaları, var olan önceki bilgiler ile yeni öğrenilenler arasında bağlantı sağlayarak anlamlı öğrenmenin gerçekleşmesine yardımcı olmaktadır.

Bireyi merkeze alan, bireyin dil becerilerini daha etkili nasıl kullanabileceğini gösteren kavram haritaları dil öğretiminde kullanılan bir tekniktir. Kalaycı ve Çakmak (2000), öğrenenler açısından kavram haritalarının bilişsel örgütlemeyi güçlendiren bir yönü olduğunu ifade etmektedir(s. 578). Bunun yanı sıra kavram haritaları öğrencilerin bilişsel becerileri hakkında öğreticilere de yol göstermektedir. Bu

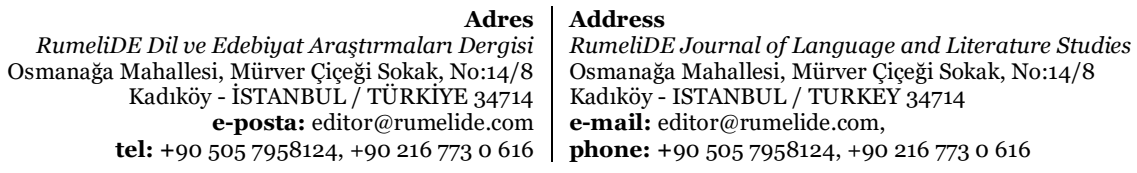


bağlamda kavram haritaları hem sözcük öğretiminde hem de okuma, dinleme, konuşma ve yazma becerilerinde kullanılabilir (Acat, 2003, Aydoğan, 2019; Durukan ve Maden, 2010; Karatay,2018; Şahin, Kurudayığlu ve Abalı Öztürk, 2013; Zorpuzan, 2019).

Türkçenin yabancı dil olarak öğretiminde öğrencilerin en çok ihtiyaç duyduğu beceri olan okuma anlama becerisinin geliştirilmesinde kavram haritalarından faydalanılabilir. Durmuş ve Okur (2013), ana dili olarak temel dil becerilerinin kazanımındaki dinleme-konuşma-okuma-yazma sıralamasının yabancı dil öğretiminde geçerli olmadığından okumanın daha önemli hale geldiğini, diğer becerilerin edinilmesinde okumaya daha büyük görevler düştüğünü belirtmektedir. (s. 293). Yani, dil öğretiminde hedef dile ait dil girdisinin çoğu okuma becerisiyle oluşturulmaktadır. Bu yönüyle okuma, diğer becerilerin de temelini oluşturmakta ve diğer becerileri desteklemektedir.

Okuma, görme ve seslendirmenin ötesinde düşünme, kavrama, değerlendirme, yorumlama gibi birçok zihinsel süreci kapsayan bir beceridir. Bu yönüyle okumada seslendirmenin yanında zihinsel bir çabaya ihtiyaç duyulmakta ve okumanın anlamayla sonuçlanması beklenmektedir. Nitekim Aytaş(2005), anlamı, okumanın en önemli unsuru olarak nitelendirmektedir (s. 462). Ancak yabancı dilde okumada, alfabe farklılıkları, söz dizimindeki farklılıklar, kültürel farklılıklar vb. öğrenenlerin daha uzun süreye ve daha fazla zihinsel çabaya gereksinim duymalarına sebep olmakta ve bu durum metinlerin anlaşılmasını zorlaştırabilmektedir. Bu bağlamda kavram haritaları, okuma metinlerinde yer alan kelimeleri, kelimeler arasındaki anlam ağını, olayların akışını, neden sonuç ilişkilerini somut ve görsel olarak yansıtabildiğinden okumanın anlam boyutunu destekleyen etkili bir öğretim tekniğidir.

Bütün bu gerekçeler doğrultusunda bu araştırmada Türkçe öğrenen yabancı öğrencilerin, okuduğunu anlama becerisi üzerinde kavram haritalarının etkisi araştırılmıştır. Bunun yanı sıra kavram haritasıyla ilgili çalışmalar incelendiğinde, çalışmaların özellikle fen ve matematik alanlarında(Altınok, 2004; Oluk, 2016; Duru, 2001; Özata, 2003;Kabaca, 2002) yoğunlaştığı görülmektedir. Son yıllarda sosyal bilgiler, yabancı dil öğretimi, Türkçenin ana dili olarak öğretimi gibi alanlarda da bu konuyla ilgili çalışmaların (Acat, 2003; Aydoğan, 2019; Beydoğan, H.Ö., 2010; Çolak, 2010; Durukan ve Maden, 2010; Girgin, 2012; Korukcu, 2007; Onan, 2016; Öztürk ve Ömeroğlu, 2015; Pınar, 2018; Polatcan, 2013; Şahin vd. 2013; Şenay, 2007; Tavşanlı, 2014; Yaman, 2006; Varol, 2018) sayısı artmıştır. Ancak, Türkçenin yabancı dil olarak öğretimi alanında bu konuyla ilgili sınırlı sayıda çalışmanın (Bülbül, 2015; Maden, Altunbay ve Dinçel, 2016; Kurudayığlu ve Zorpuzan, 2019) varlığından söz edilebilir. Bu açıdan bakıldığında bu araştırmanın, alan yazındaki eksikliği gidererek yabancı dil olarak Türkçe öğretiminde kavram haritası kullanımı üzerine ileride yapılacak çalışmalara yol göstereceği düşünülmektedir.

\section{Kavram haritaları}

Yabancı dil öğretiminde hedeflenen kazanımlara ulaşabilmek amacıyla geçmişten bugüne birçok yaklaşım, yöntem ve strateji ortaya atılmıştır. Zamanla öğretmen merkezli öğretimin yerini öğrenci merkezli öğretimin alması, ezberci öğrenmenin yerini anlamlı öğrenmeye bırakmasıyla, dil öğretiminde de yeni öğretim yöntem ve tekniklerine yer verilmeye başlanmıştır. Dil öğretiminde kullanılan güncel tekniklerden biri olan kavram haritaları, kavramlar arasındaki bağlantıların zihinde hiyerarşik olarak yapılandırılmasını ve anlamlı öğrenmeyi sağlayan görsel araçlardır. Nowak ve Gowin (1984), kavram haritasını kavramların en genel olandan daha az genele doğru hiyerarşik olarak düzenlendiği bir teknik olarak ifade ederken; Jacobs-Lawson, ve Hershey (2002) kavram haritalarını, uzun süreli bellekte bulunan anlamlı bilgiyi gösteren, hiyerarşik biçimde oluşturulmuş bilginin temsil edildiği grafikler olarak tanımlamaktadır.

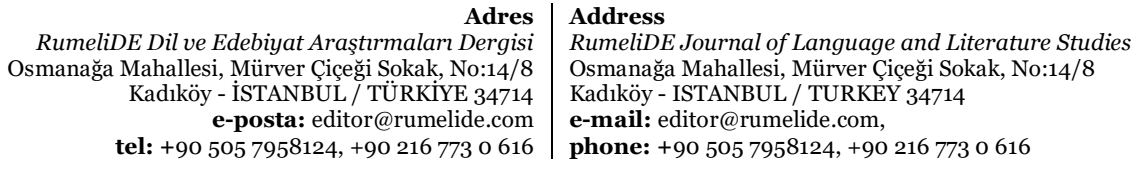


Kavram haritalarının çıkış noktası Ausubel'in anlamlı öğrenme teorisine dayanmaktadır. Nitekim Kılınç (2007), kavram haritalarının Ausubel'in teorisinde yer alan bilişsel yapının aşamalı olarak oluştuğu, yeni kavramların mevcut kavramlarla bütünleşerek geliştiği gibi görüşlere, yani anlamlı öğrenmeye bağlı kalınarak ilk defa 1970'li yllarda Joseph Novak ve Cornell Üniversitesi mezunu öğrenciler tarafından geliştirildiğini ifade etmektedir. Anlamlı öğrenmede, öğrenmeyi etkileyen en önemli faktör öğrenenin ne bildiği, yani ön bilgisidir. Dolayısıyla mevcut olan bilgilerle yeni öğrenilenler arasında bağlantılar kurarak öğrenmeyi esas alan bu öğrenmenin gerçekleştirilmesinde kavram haritaları önceki bilgilerle yeni bilgiler arasında bağlantı kurarak anlamlı öğrenmeyi kolaylaştırmaktadır. Kavram haritaları, başlangıçta öğrenmenin nasıl gerçekleştiği ve öğrenme sürecindeki bilişsel değişimleri anlamak amacıyla kullanılsa da zamanla anlamlı öğrenmeyi kolaylaştıran araçlar olarak öğretimde kullanılmaya başlanmıştır. Kavram haritaları günümüzde matematikten edebiyata, coğrafyadan dil öğretimine kadar farklı eğitim alanlarında ve farklı disiplinlerde kullanılmaktadır.

Alan yazında kavram haritaları için "strateji, yöntem, teknik, semantik haritalama, grafik örgütleyici, bilgi haritalama” gibi farklı ifadelerin kullanıldı̆̆ı görülmektedir. Nitekim alan yazın incelendiğinde kavram haritalarının öğrenme stratejisi olarak kullanıldığı çalışmalara(Belet, 2005; Girgin,2012; Kılınç, 2007), grafik düzenleyici olarak ele alındığı çalışmalara (Kansızoğlu,2017; Tavşanlı ve Kaldırım, 2020), yöntem veya teknik olarak ifade edildiği çalışmalara(Aydoğan, 2019; Yaman,2006; Zorpuzan,2019) rastlanmaktadır. Girgin(2012, s.113) kavram haritalama çalışmalarında kavram haritaları için farklı terimlere veya ifadelere yer verilmesinin karmaşıklığa sebep olduğunu ve bu durumun bu konudaki bütüncül yaklaşımı engelleyen sebeplerden biri olduğunu belirtmektedir. Bunun yanı sıra benzer bir durum kavram haritası türlerinin ifadesinde ve sinıflandırılmasında da görülmektedir. Bu konuda yapılan çalışmalar incelendiğinde farklı türde kavram haritalarına yer verildiği görülmektedir. Alan yazında farklı türde kavram haritaları görülse de kavram haritalarının temel unsurları değişmemekte, bütün türlerde anahtar/genel kavram, ilişkili kavramlar ve bağlantılar bulunmaktadır. Bu çalışmada gerek araştırmanın kapsamı gerekse kavram haritalarının yabancı dil öğretiminde kullanılan teknikler arasında yer almasından dolayı kavram haritası tekniği olarak faydalanılmış ve uygulama sürecinde okuma metinleri işlenirken farklı türde (hiyerarşik kavram haritası, örümcek kavram haritası, zincir kavram haritası, sınıflama kavram haritası ve balık kılçı̆̆ı kavram haritası) kavram haritalarına yer verilmiştir.

\section{Araştırmanın amacı}

Bu araştırmanın amacı, kavram haritasıyla öğretimin Türkçeyi yabancı dil olarak öğrenen öğrencilerin okuduğunu anlama başarısı üzerindeki etkisini belirlemektir. Bu kapsamda araştırmanın amacı olan "Kavram haritasıyla öğretimin yapıldı̆̆ı deney grubu ile bu eğitimi almayan kontrol grubu arasında okuduğunu anlama başarısı bakımından anlamlı bir fark var mıdır?” sorusuna yanıt aranmıştır.

Bu amaç doğrultusunda alt sorulara da cevap aranmıştır:

- Deney grubunun ön test ve son test puanları arasında anlamlı bir fark var mıdır?

- Kontrol grubunun. ön test ve son test puanları arasında anlamlı bir fark var mıdır?

- Deney ve kontrol grubunun son test puanları arasında anlamlı bir fark var mıdır?

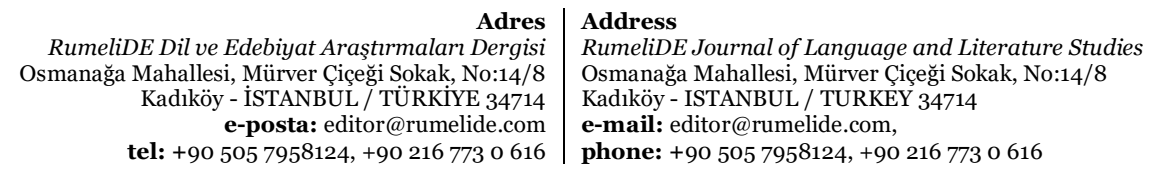


- Kavram haritasıyla öğretimin yapıldı ̆̆ı deney grubunun okuduğunu anlama başarıları cinsiyete, yabancı dil bilme durumuna, Türkiye'de bulunma süresine, kitap, gazete, dergi vb. okuma durumuna göre anlamlı bir farklılık göstermekte midir?

\section{Yöntem}

\section{Araștırmanın modeli}

Kavram haritalarının okuduğunu anlama başarısı üzerine etkisinin incelendiği bu araştırmada, ön testson test kontrol gruplu desen kullanılmıştır. Bu desen, "deneysel işlemin bağımlı değişken üzerindeki etkisinin test edilmesiyle ilgili olarak araştırmacıya yüksek bir istatistiksel güç sağlayan, elde edilen bulguların neden sonuç bağlamında yorumlanmasına olanak veren ve davranış bilimlerinde sıklıkla kullanılan güçlü bir desendir" (Büyüköztürk, 2016, s. 24). Bu çalışmada bağımlı değişkenlere (okuduğunu anlama başarısı) bağımsız değişkeninin (kavram haritaları) etkisi incelenmiştir. Araştırma deseni aşağıdaki tabloda sunulmuştur:

Tablo 1. Araştırmaya ait deneysel desen görünümü (OABT*: Okuduğunu anlama başarı testi)

\begin{tabular}{llll}
\hline & Ön Test & Deneysel İşlem & Son Test \\
\hline Deney Grubu & OABT $^{*}$ & Kavram Haritasılla Öğretim & OABT \\
Kontrol Grubu & OABT & Mevcut Öğretim Programı & OABT \\
\hline
\end{tabular}

Deney grubundaki öğrencilerin okuma anlama derslerinde kavram haritalarıyla öğretim yapılırken kontrol grubunda mevcut öğretim programıla öğretim sürecine devam edilmiştir. Deneysel işlemin başında ve sonunda her iki grup öğrencilerine okuduğunu anlama başarı testleri uygulanmıştır.

\section{Çalışma grubu}

$\mathrm{Bu}$ araştırmanın çalışma grubunu Adana Alparslan Türkeş Bilim ve Teknoloji Üniversitesi, Türkçe Öğretimi Uygulama ve Araştırma Merkezi’nde (ATÜ TÖMER) Türkçe öğrenen B1 seviyesindeki öğrenciler oluşturmaktadır. Araştırma 2017- 2018 eğitim öğretim yılı bahar döneminde ATÜ TÖMER'de Türkçe öğrenen 16'sı deney grubunda, 15’i kontrol grubunda olmak üzere toplam 31 öğrenci ile yürütülmüştür.

Deneysel işlem öncesinde grupların benzerlik durumlarını belirlemek amacıyla okuduğunu anlama başarı testinin ön test uygulaması sonucunda elde edilen puanlarda anlamlı bir fark olup olmadı̆̆ının tespiti için yapılan ilişkisiz örneklemler $t$ testi sonuçlarına aşağıdaki tabloda yer verilmiştir:

Tablo 2. Deney ve kontrol gruplarının ön test sonuçları

\begin{tabular}{llllllll}
\hline & & $\mathrm{N}$ & $\mathrm{X}$ & $\mathrm{S}$ & $\mathrm{sd}$ & $\mathrm{T}$ & $\mathrm{P}$ \\
\hline \multirow{2}{*}{ Ön Test } & Kontrol & 15 & 71,26 & 13,26 & 29 & .400 & .692 \\
& Deney & 16 & 69,37 & 13,07 & & & \\
\hline
\end{tabular}

Tablodaki sonuçlar incelendiğinde kontrol grubundaki öğrencilerin okuduğunu anlama başarı testi ön test puanlarının ortalaması 71,26, deney grubundaki öğrencilerin ise 69,37 olarak görülmektedir. Bu farkın anlamlı olup olmadığını belirlemek için yapılan analiz sonucunda iki grup arasında anlamlı bir farkın olmadığı (o.692>0.05) görülmektedir. Buna göre, uygulama öncesinde grupların birbirine benzer olduğu görülmüştür.

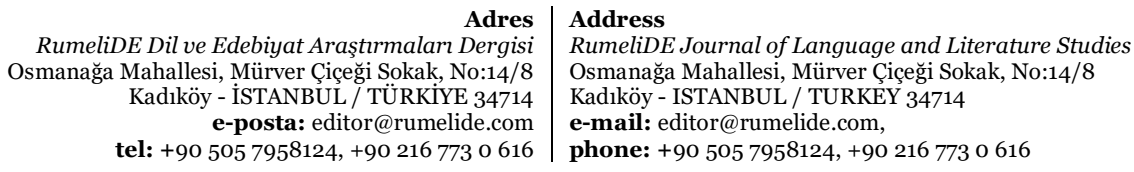




\section{Veri toplama araçları}

$\mathrm{Bu}$ araştırmada okuduğunu anlama başarı testleri veri toplama aracı olarak kullanılmıştır. Araştırmacı tarafından geliştirilen okuduğunu anlama testlerinin hazırlanma aşamaları şu şekildedir: Uygulama yapılan dil seviyesinde Diller İçin Avrupa Ortak Öneriler Çerçevesinde belirtilen kazanımlar kapsamında alan yazını taraması yapılarak benzer okuduğunu anlama başarı testleri incelenmiştir. Okuduğunu anlama başarı testinde kullanılan okuma metinleri ATÜ TÖMER'de kazanımlara uygun olarak hazırlanan okuma soruları sınav havuzundan seçilmiştir. Okuma metinleri seçilirken içerik, dil seviyesi ve kazanımlara uygunluk gözetilerek metin taraması yapılmış ve bu doğrultuda B1 seviyesi için metinler belirlenmiştir. Çalışmada kullanılan okuma metinlerinin kapsam geçerliliğini sağlamak amacıyla okuma metinleri uzman görüşüne sunulmuştur. Nitekim Büyüköztürk vd. (2014), kapsam geçerliliğini incelemede kullanılan mantıksal yollardan birinin de uzman görüşüne başvurmak olduğunu ifade etmektedir(s.117 ). Uzman görüşleri doğrultusunda seçilen metinler okuduğunu anlama başarı testi olarak kullanılmıştır. Bunun yanı sıra seçilen metinlere yönelik 30 maddeden oluşan sorular hazırlanmıştır. Farklı soru türlerinde hazırlanan sorular uzman değerlendirmesine sunulmuştur. Alan uzmanlarının önerileri doğrultusunda uygun olmadığı belirtilen 3 soru çıkarılmış, 1 soru ise öneriler doğrultusunda yeniden düzenlenmiştir. Son hâli 26 maddeden oluşan testin pilot çalışması yapılmıştır. Buna göre uygulama sonuçları madde ayırt ediciliği ve madde güçlüğü yönüyle incelenmiştir. Yapılan analizler neticesinde testte yer alan soruların bu yönlerden uygun olduğu ve başarı testine ait ortalama güçlük değerinin 0.622 olduğu tespit edilmiştir. Buna göre testin orta güçlükte olduğu ifade edilebilir. Teste ait güvenirlik KR2o değeri 0.932 şeklinde hesaplanmıştır. Büyüköztürk (2019), güvenirlik katsayısının 0.70 ve üzerinde olmasının bir testin güvenirliğinin belirlenmesinde yeterli olduğunu ifade etmektedir(s. 183). Buna göre yapılan analizler bu testin araştırmada kullanılabilecek güvenirlikte olduğunu göstermektedir. Ayrıca çalışma grubunda yer alan öğrencilerle ilgili bilgilere araştırmacı tarafından geliştirilen kişisel bilgi formuyla ulaşılmıştır.

\section{Uygulama süreci}

Araştırmanın deney grubunda öğrencilerin kavram haritası tekniğini tanımaları amacıyla uygulamanın ilk haftasında öğrencilere kavram haritasıyla ilgili bilgiler verilmiştir. Deney grubunda kur tamamlanana kadar geçen süreç(6 hafta) boyunca, "Yunus Emre Enstitüsü Türkçe Öğretim Seti" B1 seviyesi ders kitabında yer alan okuma metinleri araştırmacı tarafından çizilen kavram haritalarıyla işlenmiştir. Aşağıda ders kitabında yer alan "Haberler" ve "Nevruz Bayramı" başlıklı okuma metinleri için hazırlanan kavram haritası örneklerine yer verilmiştir:

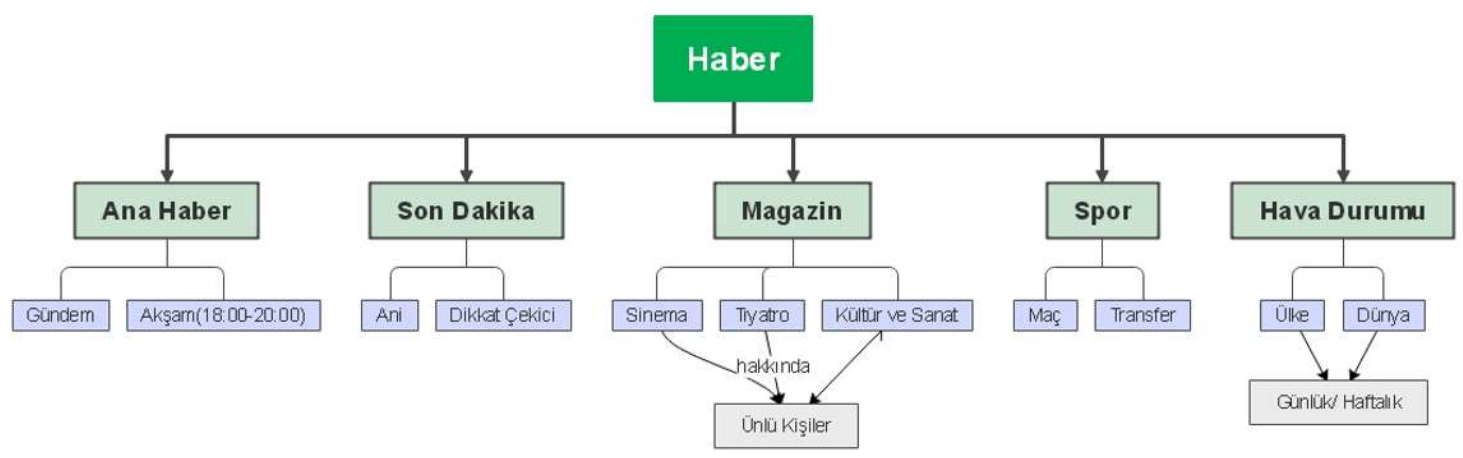

Şekil 1. Uygulama sürecinde kullanılan kavram haritası örneği 1

\begin{tabular}{r|l} 
Adres & Address \\
RumeliDE Dil ve Edebiyat Araştırmaları Dergisi & RumeliDE Journal of Language and Literature Studies \\
Osmanağa Mahallesi, Mürver Çiçeği Sokak, No:14/8 & Osmanağa Mahallesi, Mürver Çiçeği Sokak, No:14/8 \\
Kadıköy - İSTANBUL / TÜRKIYE 34714 & Kadı̈öy - ISTANBUL / TURKEY 34714 \\
e-posta: editor@rumelide.com & e-mail: editor@rumelide.com, \\
tel: +90 505 7958124, +90 216 773 o 616 & phone: +90 505 7958124, +90 216773 o 616
\end{tabular}




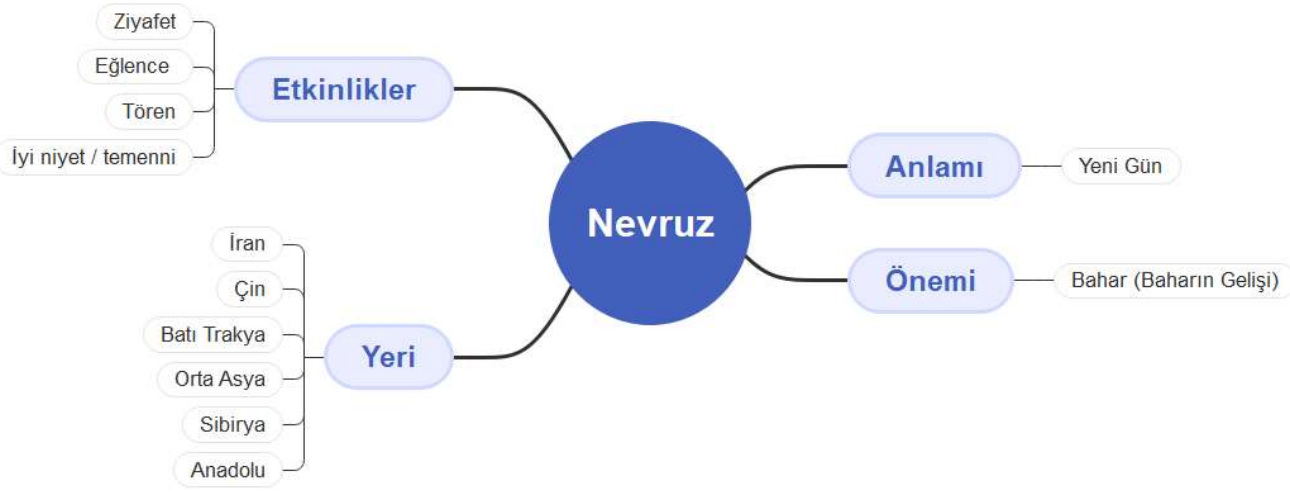

Şekil 2. Uygulama sürecinde kullanılan kavram haritası örneği 2

Ayrıca araştırmacı tarafından kavram haritasına yönelik ders planları hazırlanmış ve dersler bu planlar doğrultusunda anlatılmıştır. Kur sonunda her iki grupta yer alan öğrencilere okuduğunu anlama başarı testi uygulanmıştır.

\section{Verilerin analizi}

Veri toplama araçlarıyla ulaşılan bilgilerin analizinde SPSS 21 programı kullanılmıştır. Toplanan verilerin analizinden önce verilerin normallik testleri yapılmıştır. Ardından, deney ve kontrol grupları arasında okuduğunu anlama başarı puanlarının karşılaştırmaları ve deney grubunun okuduğunu anlama başarısı üzerinde farklı faktörlerin etki durumu ilişkisiz örneklemler $t$ testiyle analiz edilirken, deney ve kontrol gruplarında ön test-son test karşılaştırması ise ilişkili örneklemler $\mathrm{t}$ testiyle incelenmiştir.

\section{Bulgular}

Araştırmanın "Deney grubunun okuduğunu anlama başarı testi ön test ve son test puanları arasında anlamlı bir fark var mıdır?” sorusu kapsamında deney grubuna uygulama öncesinde ve uygulama sonrasında yapılan okuduğunu anlama başarı testinden elde edilen veriler incelenmiştir. Deney grubunun puan ölçümleri arasında anlamlı bir fark olup olmadığı ilişkili örneklemler t testinden faydalanılarak analiz edilmiştir. Bununla ilgili sonuçlar aşağıda tablo olarak gösterilmiştir:

Tablo 3. Deney grubunun okuduğunu anlama başarı puanlarının analiz sonuçları

\begin{tabular}{llllllll}
\hline & & $\mathrm{X}$ & $\mathrm{n}$ & $\mathrm{S}$ & $\mathrm{sd}$ & $\mathrm{T}$ & $\mathrm{P}$ \\
\hline \multirow{2}{*}{ Deney } & Öntest & 69,37 & 16 & 13,078 & 15 & 4.398 & .001 \\
& Sontest & 84,75 & 16 & 11,590 & & & \\
\hline
\end{tabular}

Tablo 3'te deney grubunun ön test ortalamaları 69,37 iken, uygulama yapıldıktan sonra son test ortalamaları 84,75 değerine ulaşmıştır. Aradaki puan farkının anlamlı olup olmadığını belirlemek amacıyla yapılan analiz sonucunda başarı puanları arasında anlamlı farklılıklar olduğu bulunmuştur $[\mathrm{t}(15)=4.398, \mathrm{p}<.05]$.

Araştırmanın ikinci alt probleminde "Kontrol grubu öğrencilerinin okuduğunu anlama başarı testi ön test ve son test puanları arasında anlamlı bir fark var mıdır?" sorusuna cevap aranmıştır. Kontrol 
grubunun puan ölçümleri arasındaki farkın anlamlı olup olmadığını belirlemek için ilişkili örneklemler t testi kullanılmıştır. Aşă̆ıdaki tabloda bununla ilgili analiz sonuçları gösterilmiştir:

Tablo 4. Kontrol grubunun okuduğunu anlama başarı puanlarının analiz sonuçları

\begin{tabular}{llllllll}
\hline \multirow{2}{*}{ Kontrol } & & $\mathrm{X}$ & $\mathrm{n}$ & $\mathrm{S}$ & $\mathrm{sd}$ & $\mathrm{T}$ & $\mathrm{P}$ \\
& Öntest & 71,26 & 15 & 13,269 & 14 & .133 & .537 \\
& Sontest & 73,86 & 15 & 10,126 & & & \\
\hline
\end{tabular}

Tabloda yer alan sonuçlara göre kontrol grubunun ön test ortalamaları 71,26 iken, son test ortalamaları 73,86 olarak görülmektedir. Bununla birlikte kontrol grubunun okuduğunu anlama puanları arasında anlamlı farklılıklar olmadı̆̆ tespit edilmiştir [t(14)=.133, p<.05].

Araştırmanın üçüncü alt problemi olan "Deney ve kontrol gruplarının okuduğunu anlama başarı testinden aldıkları son test puanları arasında anlamlı bir fark var mıdır?" sorusu kapsamında kavram haritalarının uygulandığı deney grubu ve mevcut programla öğretimin yapıldığı kontrol grubu öğrencilerinin okuduğunu anlama başarı testinden aldıkları son test puanları incelenmiştir. Gruplar arasında anlamlı bir farkın olup olmadığının tespiti için uygulanan ilişkisiz örneklemler t testi sonuçları aşağıdaki tabloda gösterilmiştir:

Tablo 5. Kontrol ve deney grubunun okuduğunu anlama başarı puanlarının analiz sonuçları

\begin{tabular}{lllllll}
\hline & $\mathrm{N}$ & $\mathrm{X}$ & $\mathrm{S}$ & $\mathrm{sd}$ & $\mathrm{T}$ & $\mathrm{P}$ \\
\hline Kontrol & 15 & 73,86 & 10,126 & 29 & 2.776 & .010 \\
Deney & 16 & 84,75 & 11,590 & & & \\
\hline
\end{tabular}

Tablodan elde edilen verilere göre kontrol grubunun puanlarının ortalaması $(73,86)$, deney grubunun ortalamasına $(84,75)$ göre daha düşüktür. Başka bir ifadeyle kavram haritasının uygulandı̆̆ı deney grubundaki öğrencilerin okuduğunu anlama başarı puanlarının kontrol grubundaki öğrencilere oranla daha yüksek olduğu görülmektedir. Ayrıca iki grup arasında anlamlı bir farklılık bulunmuştur $[\mathrm{t}(29)=2.776, \mathrm{p}<.05]$. Bu sonuçlardan hareketle öğrencilerin okuduğunu anlama başarıları üzerinde kavram haritasıyla öğretimin mevcut programla yapılan öğretimden daha etkili olduğu söylenebilir.

Araştırmanın son alt problemi doğrultusunda, "Kavram haritasıyla öğretim yapılan deney grubunun okuduğunu anlama başarıları cinsiyete, yabancı dil bilme durumuna, Türkiye'de bulunma süresine, kitap, gazete, dergi vb. okuma durumlarına göre anlamlı bir farklılık göstermekte midir?” sorusuna cevap aranmıştır. Deney grubunun son test verileri üzerinde ilişkisiz örneklemler t testi yapılarak ulaşılan sonuçlar aşağıdaki tablolarda sırasıyla gösterilmiş̧ir:

Tablo 6. Deney grubu öğrencilerinin cinsiyet durumuna göre okuduğunu anlama analiz sonuçları

\begin{tabular}{clccccccc}
\hline & & $\mathrm{N}$ & $\mathrm{X}$ & $\mathrm{S}$ & $\mathrm{sd}$ & $\mathrm{T}$ & $\mathrm{P}$ & \\
\hline \multirow{2}{*}{ Deney } & Erkek & 10 & 79,20 & 11,173 & 14 & 3.104 & .008 \\
& $\mathrm{Kiz}$ & 6 & 94,00 & 3,741 & & & & \\
\hline
\end{tabular}

Analiz sonuçlarına göre kız öğrencilerin puan ortalamaları erkek öğrencilerin puan ortalamalarından daha yüksek bulunmuştur. Ayrıca, deney grubundaki öğrencilerin başarı puanlarının cinsiyet değişkenine göre anlamlı olduğu bulunmuştur [t(14)=3.104, p<.05].

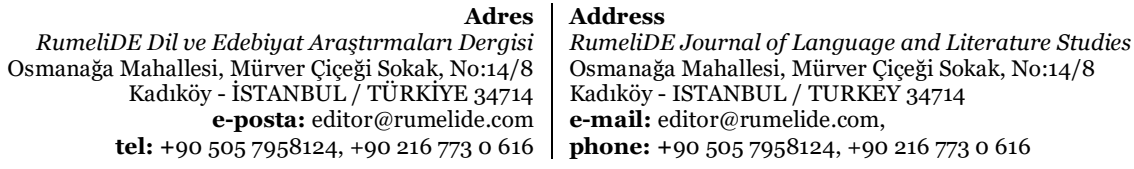


Tablo 7. Deney grubu öğrencilerinin yabancı dil bilme durumuna göre okuduğunu anlama analiz sonuçları

\begin{tabular}{llllllll}
\hline & & $\mathrm{N}$ & $\mathrm{X}$ & $\mathrm{S}$ & $\mathrm{sd}$ & $\mathrm{T}$ & $\mathrm{P}$ \\
\hline \multirow{2}{*}{ Deney } & Evet & 8 & 84,62 & 11,338 & 14 & .042 & .967 \\
& Hayır & 8 & 84,87 & 12,620 & & & \\
\hline
\end{tabular}

Tablo 7’ye göre deney grubu öğrencilerinden yabancı dil bilenlerin son test puan ortalaması 84,62 iken yabancı dil bilmeyen öğrencilerin puan ortalaması 84,87'dir. Deney grubundaki öğrencilerin yabancı dil bilme durumuna göre puanlarının anlamlı farklılığa yol açmadığı bulunmuştur( ( t14)=,042; p>.05).

Tablo 8. Deney grubu öğrencilerinin Türkiye'deki yaşam sürelerine göre okuduğunu anlama analiz sonuçları

\begin{tabular}{|c|c|c|c|c|c|c|c|}
\hline & & $\mathrm{N}$ & $\mathrm{X}$ & $\mathrm{S}$ & sd & $\mathrm{T}$ & $\mathrm{P}$ \\
\hline \multirow{2}{*}{ Deney } & 1-3 yll & 9 & 85,55 & 11,435 & 14 & .306 & .764 \\
\hline & 3 yıl üstü & 7 & 83,71 & 12,618 & & & \\
\hline
\end{tabular}

Tablo incelendiğinde Türkiye'deki yaşam süresi 1-3 yll olan öğrencilerin puan ortalaması 85,55 iken Türkiye'deki yaşam süresi 3 yıl ve üzeri olan öğrencilerin puan ortalaması 83,71'dir. Deney grubundaki öğrencilerin Türkiye'deki yaşam sürelerine göre dil seviyeleri arasındaki puan farklılıkların anlamlı olmadığı ortaya çıkmıştır. [t(14)=.306, p<.05].

Tablo 9. Deney grubun öğrencilerinin kitap, gazete, dergi vb. okuma durumlarına göre okuduğunu anlama analiz sonuçları

\begin{tabular}{llllllll}
\hline & & $\mathrm{N}$ & $\mathrm{X}$ & $\mathrm{S}$ & $\mathrm{sd}$ & $\mathrm{T}$ & $\mathrm{P}$ \\
\hline \multirow{2}{*}{ Deney } & Evet & 6 & 93,16 & 5,671 & 14 & 2.671 & .018 \\
& Hayir & 10 & 79,70 & 11,421 & & & \\
\hline
\end{tabular}

Tablo 9 incelendiğinde kitap, gazete, dergi vb. okuyan öğrencilerin puan ortalaması 93,16, kitap, gazete, dergi vb. okumayan öğrencilerin puan ortalaması 79,70'dir. Yapılan analiz neticesinde deney grubundaki öğrencilerin kitap, gazete, dergi vb. okuma durumlarına göre puanlarının anlamlı farklılaştığı bulunmuştur $[\mathrm{t}(14)=2.671, \mathrm{p}<.05]$.

Yapılan analizler neticesinde elde edilen bütün bu bulgular, gruplar arasında deney grubu ve deneysel işlem lehine anlamlı bir fark olduğunu, okuduğunu anlama becerisinde kavram haritasının kullanımının mevcut öğretime göre daha etkili olduğunu göstermektedir.

\section{Sonuç, tartışma ve öneriler}

Uygulama öncesinde kontrol ve deney grubunun okuduğunu anlama başarı testi puan ortalamalarının birbirine yakın olduğu ve gruplar arasında anlamlı bir fark olmadığı bulunmuştur. Bu durum çalışma gruplarının uygulama öncesinde okuduğunu anlama becerisi başarısı bakımından birbirine yakın seviyede olduğu şeklinde yorumlanabilir.

Uygulama sonrasında yapılan analiz sonuçlarına göre, deney grubu öğrencilerinin başarı puanları arasında istatiksel olarak anlamlı bir farkın olduğu tespit edilmiştir. Bu durum kavram haritasıyla öğretimin deney grubunun okuduğunu anlama başarısı üzerinde etkili olduğunu göstermektedir. Kontrol grubunun okuduğunu anlama başarı puanları arasında ise anlamlı bir fark bulunamamıştır. Yani mevcut öğretim programıyla yapılan öğretimin kontrol grubunun okuduğunu anlama başarısı

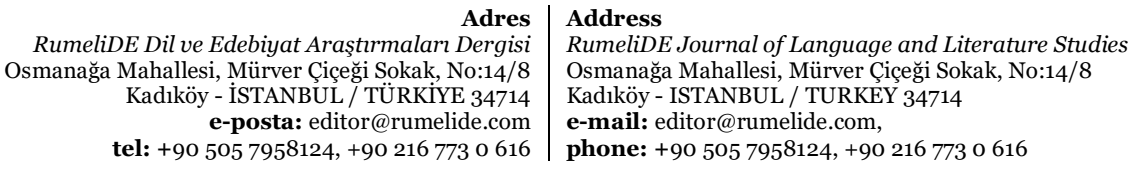


üzerinde anlamlı bir etkisi olmamıştır. Her iki grubun okuduğunu anlama başarı testinden aldıkları puanlar karşılaştırıldığında deney grubu lehine anlamlı bir farklılık bulunmuştur. Bu bulgular okuduğunu anlama başarısı üzerinde kavram haritasıyla yapılan öğretimin mevcut öğretim programına göre yapılan öğretimden daha etkili olduğu sonucunu ortaya çıarmıştır. Bu sonuç, farklı disiplinlerde kavram haritalarının etkisinin araştırıldığı bazı araştırma sonuçlarıyla (Çolak, 2010; Korukcu, 2007; Tümen, 2006) benzerlik göstermektedir. Tümen (2006), yaptığı çalışmada yabancı dil öğretiminde kavram haritalarının öğrenci başarısına etkisini araştırmıştır. Bu çalışmada İngilizce derslerinde deney grubunda kavram haritası yöntemi kullanılırken kontrol grubunda dersler geleneksel öğretim yöntemiyle işlenmiştir. Korukcu'nun(2007) çalışmasında din kültürü derslerinde deney grubunda kavram haritaları kullanılırken kontrol grubunda geleneksel öğretim yapılmıştır. Çolak(2010), sosyal bilgiler öğretiminde kavram haritalarının başarıya, tutuma ve kalıcllı̆a etkisini araştırdığı çalışmasında deney grubunda kavram haritası tekniğini kullanmıştır. Her üç çalışmada da elde edilen verilerin analizi sonucunda kavram haritasıyla öğretimin daha etkili olduğu sonucuna ulaşılmıştır.

Daha yerinde bir karşılaştırma yapmak için benzer çalışmaları ana dili öğretiminde ve yabancı dil olarak Türkçe öğretiminde yapılan çalışmalar kapsamında sınırlandırmak daha isabetli olacaktır. Nitekim bu çalışmaların (Aydoğan, 2019, Bülbül, 2015; Girgin, 2012; Maden vd., 2016; Polatcan, 2013; Zorpuzan, 2019) sonuçlarıyla bu araştırmadan elde edilen sonuçlar örtüşmektedir. Girgin(2012) 8. sınıf Türkçe derslerinde okuduğunu anlama başarısı ve kalıcılık üzerinde kavram haritalarının etkisini araştırdığı çalışmada kavram haritasının başarı ve kalıcılık üzerinde olumlu etkisinin olduğu sonucuna ulaşmıştır. Polatcan'ın (2013) dil bilgisi öğretiminde kavram haritalarının etkisini araştırdığı çalışmada ve Aydoğan'ın (2019) öğrencilerin konuşma becerisinin geliştirilmesinde kavram haritalarının etkisini araştırdığı çalışmada kavram haritalarının geleneksel öğretime göre daha etkili bir öğretim aracı olduğu sonucuna ulaşılmıştır. Türkçenin yabancı dil olarak öğretimi alanında bu konuda sınırlı sayıda çalışma bulunmaktadır. Bülbül (2015), Türkçe öğrenen C1 düzeyi öğrencilerinin okuma becerilerinin kavram haritaları aracılığıyla geliştirilmesini amaçlamıştır. Eylem araştırması şeklinde yürütülen çalışmada kavram haritalarının öğrencilerin tahmin etme, özetleme ve soru üretme becerilerini geliştirdiği sonucuna ulaşlmıştır. Zorpuzan(2019) kavram haritalarının kelime öğretimi üzerindeki etkisini araştırdığı çalışmasında kavram haritası tekniğinin öğrenciler üzerinde geleneksel öğretimden daha etkili olduğu sonucuna ulaşmıştır. Maden vd. (2016), çalışmalarında kavram haritalarının etkili bir öğretim yöntemi olarak sözcük öğretiminde kullanılabileceğini göstermişlerdir. Yukarıda bahsedilen çalışmaların sonuçlarıyla bu çalışmanın sonucu benzerlik göstermektedir.

Deney grubu öğrencilerinin okuduğunu anlama başarıları üzerinde cinsiyetin etki durumu incelendiğinde kız öğrencilerin erkek öğrencilerden daha yüksek puanlar aldığı ve bu puanların anlamlı olduğu tespit edilmiştir. Bu durum deney grubundaki kız öğrencilerin yeni öğretim yöntem ve tekniklerini kullanmaya daha istekli oldukları şeklinde yorumlanabileceği gibi kavram haritasıyla yapılan öğretimi daha çabuk benimsedikleri şeklinde de yorumlanabilir. Araştırmanın bu sonucu Çatalkaya(2005) ve Polatcan'ın (2013) çalışma sonuçlarıyla kısmen benzerlik gösterse de tam olarak örtüşmemektedir. Nitekim Çatalkaya'nın (2005) bireysel farklılıkların kavram haritası yapabilme başarısına etkisini araştırdığı çalışmada, kavram haritası yapma başarısında cinsiyetin etkisi olup olmadığı da incelenmiştir. Yapılan analizlere göre deney grubunda bulunan kız öğrencilerin başarı puanları erkek öğrencilerin başarı puanlarından daha yüksek bulunmuş, ancak anlamlı bir farklılık tespit edilmemiştir. Yine Polatcan'ı (2013) dil bilgisi öğretiminde kavram haritalarının etkisini araştırdığı çalışmasında deney grubunda bulunan kız öğrencilerin puan ortalamaları erkek öğrencilerin puanlarından daha yüksek bulunsa da puanlar arasında anlamlı bir farklılık bulunmamıştır. Dolayısıyla

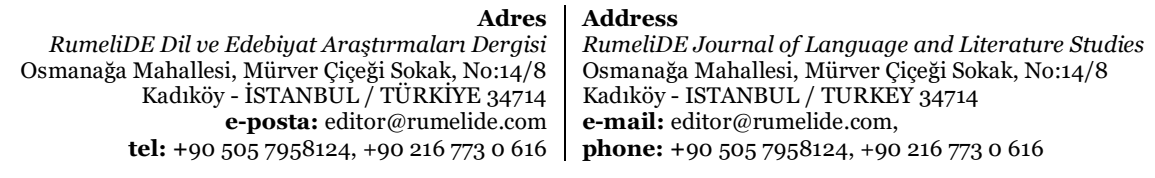


bu çalışmaların sonuçları kız öğrencilerin daha başarılı sonuçlar almaları yönüyle bu çalışmayla örtüşse de anlamlı bir farklılık bulunmaması yönüyle bu çalışmadan ayrılmaktadır.

Deney grubu öğrencilerinin yabancı dil bilip bilmeme durumu ve Türkiye'de yaşama süresinin öğrencilerin okuduğunu anlama başarıları üzerindeki etkisi analiz edildiğinde okuduğunu anlama başarısı üzerinde yabancı dil bilme durumunun ve Türkiye'de yaşama sürelerinin anlamlı bir etkisinin olmadığı sonucuna ulaşılmıştır. Bu durumda bilinen diğer yabancı dillerin ve Türkiye'de daha uzun yaşama süresine sahip olmanın okuduğunu anlama başarısını artırmada anlamlı bir etkisinin olmadığı söylenebilir. Kitap, gazete, dergi vb. okuma durumlarının öğrencilerin okuduğunu anlama başarıları üzerinde etkisi analiz edildiğinde ise anlamlı bir farklılığın olduğu bulunmuştur. Yani kavram haritasıyla öğretimin yapıldığı deney grubunda kitap, gazete, dergi vb. okuyan öğrencilerin okuduğunu anlama becerisinde diğer öğrencilere göre daha başarılı oldukları sonucuna ulaşılmıştır. Bu durum okuma anlama derslerinin dışında kitap, gazete, dergi vb. okuyan öğrencilerin kavram haritasıyla yapılan öğretimi daha kolay benimsedikleri şeklinde yorumlanabilir. Bu sonuçlar Altunkaya’nın(2015), yabancı dil olarak Türkçe öğrenenlerin okuma kaygıları ile okuduğunu anlama becerileri arasındaki ilişkisini araştırdığı çalışmasında Türkiye'de yaşama süresi bakımından ulaştığı sonuçlarla benzerlik gösterse de bilinen yabancı dil sayısı ve Türkçe kitap, gazete, dergi okuma durumu bakımından ulaştığı sonuçlarla farklılık göstermektedir. Nitekim Altunkaya(2015), çalışmasında öğrencilerin okuduğunu anlama puan ortalamalarının Türkçe kitap, dergi, gazete okuma durumlarına göre farklılaşmadığı sonucuna ulaşmıştır. Aynı çalışmada ana dili dışında bilinen yabancı dil sayısı arttıkça okuduğunu anlama başarısının arttığı tespit edilmiştir. Bununla birlikte okuduğunu anlama başarı ortalamalarına göre 6 ay-1 yıl arasında Türkiye'de kalan öğrenciler lehine anlamlı farklılık olduğu bulunmuş ve Türkiye'de daha uzun süre yaşıyor olmanın okuduğunu anlama başarısını artırmada yeterli olmayacağı sonucuna ulaşılmıştır. Ulaşılan sonuçlar bu araştırmanın sonucuyla kısmen benzerlik göstermektedir.

Sonuç olarak bu çalışma, kavram haritasıyla öğretimin okuduğunu anlama becerisi üzerinde etkili olduğunu ve okuduğunu anlama başarısında kavram haritası kullanımının mevcut programla öğretimden daha etkili olduğunu ortaya koymuştur. Bu kapsamda kavram haritalarının, Türkçeyi yabancı dil olarak öğrenen öğrencilerin okuduğunu anlama becerilerinin geliştirilmesinde etkili bir araç olarak kullanılabileceği sonucuna ulaşılmıştır.

Araştırmadan elde edilen sonuçlar doğrultusunda kavram haritasının kullanımına ve bu alanda daha sonra yapılacak olan çalışmalara yönelik aşağıdaki önerilerde bulunulabilir:

- Okuduğunu anlama becerisinde olumlu etkisi görülen kavram haritalarının dil öğretim sürecinde kullanılmasının öğretimin niteliğini artıracağı düşünülmektedir. Bu kapsamda ders kitaplarının ve öğretim materyallerinin hazırlanmasında kavram haritalarından faydalanılabilir.

- Ölçme değerlendirme aşamasında kavram haritalarından faydalanılabilir. Sınav soruları hazırlanırken kavram haritası kullanımına uygun sorulara yer verilebilir.

- Kavram haritalarının öğrenme ortamları dışında da kullanılabilmesi amacıyla farklı dil seviyelerine yönelik teknolojik uygulamalar geliştirilebilir.

- Kavram haritalarının yabancı dil olarak Türkçenin öğretiminde dinleme, konuşma ve yazma becerilerine etkisi araştırılabilir.

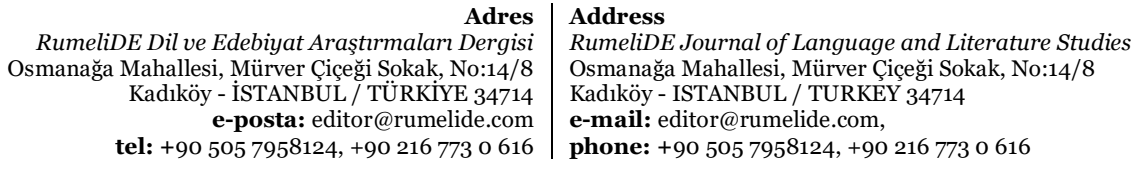


- Farklı becerilerde kullanılacak kavram haritalarının öğrencilerin tutum, kaygı ve motivasyonuna yönelik etkisi araştırllabilir.

- Çağdaş öğretim tekniklerinden biri olarak kullanılan kavram haritalarının diğer yöntem ve tekniklerle karşılaştırıldığı çalışmalar yapılabilir.

\section{Kaynakça}

Acat, B. (2003). Kavram Haritalarının Türkçe Öğretiminde Kullanımı. Kuram ve Uygulamada Eğitim Yönetimi, 34, 168-193

Altınok, H. (2004). İşbirlikli öğrenme, kavram haritalama, fen başarısı, strateji kullanımı ve tutum. (Yayımlanmamış doktora tezi). Dokuz Eylül Üniversitesi, İzmir.

Altunkaya(2015). Yabancı dil olarak Türkçe öğrenenlerin okuma kaygıları ile okuduğunu anlama becerileri arasındaki ilişki(Yayımlanmamış doktora tezi). İnönü Üniversitesi, Malatya

Aydoğan, Y. (2019). Ortaokul öğrencilerinin konuşma becerilerinin geliştirilmesinde ve konuşma kaygllarında kavram haritalarının etkisi (Yayımlanmamış yüksek lisans tezi). Kütahya Dumlupınar Üniversitesi, Kütahya.

Aytaş, G. (2005). Okuma eğitimi. Türk Eğitim Bilimleri Dergisi, 3(4), 461-470.

Belet, D. (2005). Öğrenme stratejilerinin okuduğunu anlama ve yazma becerileri ile Türkçe dersine ilişkin tutumlara etkisi (Yayımlanmamış doktora tezi). Anadolu Üniversitesi, Eskişehir.

Beydoğan, H. Ö. (2010). Grafiksel düzenlemelerin öğrencilerin okuma-anlama düzeylerine etkisi. Milli Ĕ̆itim Dergisi, 40 (188) , 202-217.

Bülbül, F. (2015). Yabancı dil olarak Türkçe öğretiminde okuduğunu anlama becerisinin kavram haritası aracılı̆̆ıla geliştirilmesi: Bir eylem araştırması. Çanakkale Onsekiz Mart Üniversitesi Eğitim Bilimleri Enstitüsü. (Yayımlanmamış doktora tezi). Çanakkale.

Büyüköztürk, Ş. (2016). Deneysel desenler öntest-sontest kontrol grubu desen ve veri analizi (5. Baskı). Ankara: Pegem Akademi.

Büyüköztürk, Ş. (2019). Sosyal bilimler için veri analizi el kitabı. Ankara: Pegem Akademi.

Büyüköztürk, Ş., Çakmak, E. K., Akgün, Ö.E., Karadeniz, Ş. \& Demirel, F. (2014). Bilimsel araştırma yöntemleri. Ankara: Pegem Akademi.

Çatalkaya, R. (2005). Bazı bireysel farklılkkların kavram haritası yapma başarısına etkisi. (Yayımlanmamış yüksek lisans tezi). Abant İzzet Baysal Üniversitesi Sosyal Bilimler Enstitüsü, Bolu.

Çolak, R. (2010). Kavram haritalarmm sosyal bilgiler eğitimi çerçevesinde tarihsel kavramlarm öğretiminde kullanılması: kavram haritası ile yapılan öğretim ile tutum, başarı ve kahculı arasındaki ilişkinin incelenmesi. (Yayımlanmamış yüksek lisans tezi). Marmara Üniversitesi, Eğitim Bilimleri Enstitüsü, İstanbul.

Demircan, Ö. (1990). Yabancı dil öğretim yöntemleri. İstanbul: Ekin Eğitim, 183-185.

Durmuş, M., \& Okur, A. (Eds.). (2013). Yabancılara Türkçe öğretimi el kitabı. Ankara: Grafiker.

Duru, M. K. (2001).illköğretim fen bilgisi dersinde kavram haritasuyla ve gruplara kavram haritası çizdirilerek öğretimin öğrenci başarısına ve hatırlamaya etkisi, (Yayımlanmamış yüksek lisans tezi). Marmara Üniversitesi Eğitim Bilimleri Enstitüsü, İstanbul.

Durukan, E. \& Maden, S. (2010). Kavram haritaları ile not tutmanın ilköğretim öğrencilerinin dinlediğini anlama becerisi üzerine etkisi. ODÜ Sosyal Bilimler Enstitüsü, Sosyal Bilimler Araştırmaları Dergisi, 1(2), ISSN: 1309-9302.

Girgin, Y. (2012). İlköğretim 8. Sinff Türkçe Ders Kitaplarındaki Metinlerde Kavram Haritası Kullanımının Öğrencilerin Okuduğunu Anlama Becerileri Üzerine Etkisi. (Yayımlanmamış doktora tezi). Türkçe Eğitimi Ana Bilim Dalı, Atatürk Üniversitesi, Erzurum.

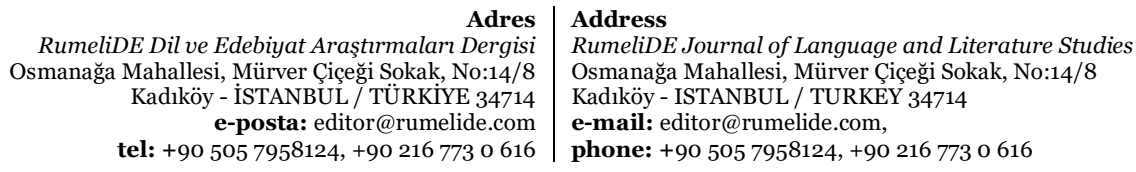


Jacobs-Lawson, J. M., \& Hershey, D. A. (2002). Concept maps as an assessment tool in psychology courses. Teaching of Psychology, 29(1), 25-29.

Kabaca, T. (2002). Orta öğretim matematik eğitiminde kavram haritalanması tekniğinin kullanımı. (Yayımlanmamış yüksek lisans tezi). Marmara Üniversitesi Fen Bilimleri Enstitüsü, İstanbul.

Kalaycı, N., \& Çakmak, M. (200o). Kavram haritalarının öğretim sürecinde kullanılması. Kuram ve Uygulamada Ĕ̆itim Yönetimi, 24(24), 571-580.

Kansızoğlu, H. B. (2017). Grafik örgütleyicilerin dil öğretme ve öğrenme alanlarındaki başarıya etkisi: bir meta analiz çalışması. Eğitim ve Bilim, 42(191), 139-164.

Karatay, H. (2018). Okuma eğitimi kuram ve uygulama. Ankara: Pegem Akademi.

Kaya, O. N. (2003). "Eğitimde alternatif bir değerlendirme yolu: Kavram haritaları", Hacettepe Üniversitesi Eğitim Fakültesi Dergisi 25, 265-271.

Kılınç, A. (2007). Bir öğretim stratejisi olarak kavram haritalarının kullanımı. Yüzüncü Yıl Üniversitesi, Ĕ̆itim Fakültesi Dergisi. Cilt:IV, (II) 21-48

Korukcu, A. (2007) Kavram haritalarının din öğretiminde kullanımı (ilköğretim din kültürü ve ahlak bilgisi dersi 7. sinıf 1. ünite Kur'an-I Kerim'i tanıyalım ünitesi örneğinde bir uygulama örneği). (Yayımlanmamış doktora tezi). Ankara Üniversitesi.

Kurudayığlu, M. \& Zorpuzan, R. (2019). Türkçenin yabancı dil olarak öğretiminde anlamsal haritalama tekniğinin kelime öğretimi üzerine etkisi. Ana Dili Eğitimi Dergisi, 7(4), 1010-1028.

Maden, S., Altunbay, M., \& Dinçel, Ö. (2016) Türkçenin yabancı dil olarak öğretiminde sözcük öğretimi uygulamaları: Kavram haritası örneği. Milli Ĕ̆itim Dergisi, 45(210), 477-488

Novak, J. D., \& Gowin, D. B. (1984). Learning how to learn. New York: Cambridge University Press.

Oluk, N. T. (2016). Kimya eğitiminde farkh kavram haritası oluşturma yöntemlerinin karşılaştırılması. (Yayımlanmamış doktora tezi). Gazi Üniversitesi Eğitim Bilimleri Enstitüsü. Ankara

Onan B. (2016). Türkçenin Ana Dili Olarak Öğretimine Beyin Temelli Yaklaşım. Zeitschrift für die Welt der Türken, Vol. 8 No. 1 (2016) 109-133

Özata, Ö. F., (2003). İlköğretim birinci kademe fen bilgisi dersinde kavram haritalarmin kavram yanılgıların gidermeye ve hatırlamaya etkisi. (Yayımlanmamış yüksek lisans tezi). Marmara Üniversitesi Ĕ̆itim Bilimleri Enstitüsü, İstanbul.

Öztürk J. Ömeroğlu A.F. (2015) Dil bilgisi öğretiminde kavram haritalarının kullanımı. Mustafa Kemal Üniversitesi Sosyal Bilimler Enstitüsü Dergisi, 12:31, s. 69-86

Pınar, F. N., (2018). Türkçe öğretiminde kavram haritalarını önemi ve anlama becerilerine ait teorik bilgilerin kavram haritası çeşitleriyle gösterilmesi. (Yayımlanmamış yüksek lisans tezi). Selçuk Üniversitesi Eğitim Bilimleri Enstitüsü, Konya.

Polatcan, F. (2013). 6. sinıflarda kavram haritalarıla dil bilgisi öğretiminin başarıya etkisi. (Yayımlanmamış yüksek lisans tezi). Atatürk Üniversitesi Eğitim Bilimleri Enstitüsü, Erzurum.

Şahin, Ç., Kurudayığlu, M., \& Abalı Öztürk, Y., (2013). Türkçe Öğretiminde kavram haritalarının kullanılması üzerine kuramsal bir çalışma. Dil ve Edebiyat Eğitimi Dergisi, vol.2, 13-34.

Şenay, A. (2007). Kavram haritaları yöntemiyle metin öğretimi. (Yayımlanmamış yüksek lisans tezi). Selçuk Üniversitesi, Konya.

Tavşanl, Ö. F. (2014). Grafik örgütleyicilerin ilköğretim 4. sımf öğrencilerinin bilgilendirici metinleri çözümleme ve özetleme başarıları üzerine etkisi (Yayımlanmamış yüksek lisans tezi). Akdeniz Üniversitesi, Eğitim Bilimleri Enstitüsü, Antalya

Tavşanlı, Ö. F., Kaldırım, A. (2020), Grafik örgütleyicilerin Türkçe eğitiminde kullanımını konu edinen araştırmaların incelenmesi: bir tematik analiz. Uludağ Üniversitesi Eğitim Fakültesi Dergisi cilt: 33 sayl: 3 sayfa: $839-873$

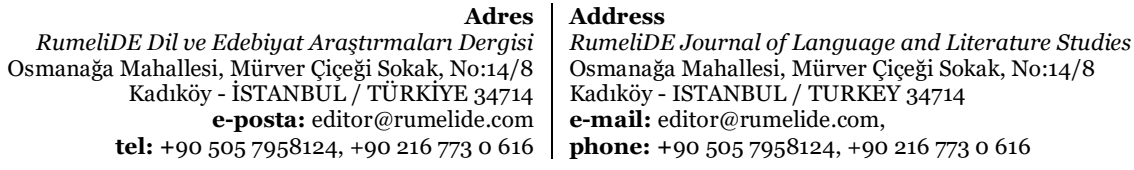


Türkçenin yabancı dil olarak öğretiminde kavram haritaları kullanımının başarıya etkisi / Z. Gürel; H. G. Gerek (110-123. s.)

Tümen, S. (2006). Kavram haritaları yönteminin yabancı dil öğretiminde öğrenci başarısına etkisi. (Yayımlanmamış yüksek lisans tezi), Fırat Üniversitesi, Elazığ.

Varol, M. (2018). Zihin yetersizliği olan çocuklara hayvanların temel özelliklerinin kazandırlmasında doğrudan ögrretim yöntemiyle sunulan kavram haritasının etkililiği. (Yayımlanmamış yüksek lisans tezi) Abant İzzet Baysal Üniversitesi Eğitim Bilimleri Enstitüsü, İstanbul.

Yalçın, A. (2012). Türkçe öğretim yöntemleri yeni yaklaşımlar. Ankara: Akçağ.

Yaman, H. (2006). İlköğretim ikinci kademe dilbilgisi derslerinde kavram haritası tekniğinin öğrenci başarısına ve hatırlamaya etkisi (Yayımlanmamış doktora tezi). Marmara Üniversitesi, İstanbul.

Zorpuzan, R. (2019). Türkçenin yabancı dil olarak öğretiminde kavram haritalarının kelime öğretimi üzerine etkisi (Yayımlanmamış yüksek lisans tezi). Bolu Abant İzzet Baysal Üniversitesi, Bolu.

RumeliDE Dil ve Edebiyat Araştırmaları Dergisi Osmanağa Mahallesi, Mürver Çiçeği Sokak, No:14/8 Kadıköy - İSTANBUL / TÜRKIYE 34714 e-posta: editor@rumelide.com tel: +90 $5057958124,+902167730616$
Address

RumeliDE Journal of Language and Literature Studies Osmanağa Mahallesi, Mürver Çiçeği Sokak, No:14/8

Kadıköy - ISTANBUL / TURKEY 34714

e-mail: editor@rumelide.com

phone: +90 505 7958124, +90 2167730616 